regarded as forming part of the series of ancient crystalline rocks. The plant-remains are identical with those found in the Old Red Sandstone rocks in Caithness, Orkney, and Shetland, from which it was inferred that the quartzites and shales in which the fossils are imbedded must be classed with this formation. The authors also described the great series of contemporaneous and intrusive igneous rocks of Old Red Sandstone age, adducing evidence in proof of the great denudation which has taken place in the members of this formation in Shetland.

3. "On the Southerly Extension of the Hessle Boulder-clay in Lincolnshire." By A. J. Jukes-Browne, Esq., B.A., F.G.S.

The southern boundary of the Hessle Clay has not hitherto been satisfactorily determined. The author traces this deposit along the border of the flat fen land in South Lincolnshire, near Burgh, Steeping, etc., and the east and west Fen. $\mathrm{He}$ concurs with $\mathrm{Mr}$. Searles Wood in believing the clay to be the product of shore-ice along a coast-line, and that the materials were in great part derived from the older "Purple Clay." He differs, however, from that author as to the correlation of the Hessle series, thinking this more probably older than the oldest river-gravels of the South-east of England. In an appendix a deep well-section at Boston is discussed, and reasons are given for assigning the greater part of the beds in this to the Jurassic Clays, not to the Glacial.

\title{
CORZESPOINDINC耳.
}

\section{THE MAMMOTH NOT PRE-GLACIAL IN BRITAIN.'}

Sir,-Many will regret that Prof. Dawkins has lent the authority of his name to the opinion that the Mammoth is pre-Glacial in Britain, but perbaps few may take the trouble to point out how very unsatisfactory is the evidence he brings forward (Quart. Journ. Geol. Soc., Feb. 1879). His evidence that the Mammoth is preGlacial in the South of England rests upon the assumption that the gravel beneath the Boulder-clay at Bricket Wood, between Watford and St. Albans, is pre-Glacial. There is no proof that it is older than the Lower Boulder-clay or Cromer Till of the Norfolk coast; on the contrary, it may be newer. And this being the case, the evidence is of no value whatever in assigning a pre-Glacial age to the animalremains found in it.

Mr. Clement Reid pointed out in a recent number of "Nature" (vol. xix. p. 122) that there was no evidence to show that any single specimen of the Elephas primigenius had been obtained in situ from the pre-Glacial or Forest Bed series of the Cromer coast-a conclusion which only bore out the repeated statements of Mr. Gunn and others. As the subject is one of great interest, perhaps Prof. Dawkins will kindly state where are to be seen those specimens upon which he founds his opinion that the Mammoth has been found in the Forest Beds. Horace B. WOODWARD.

ArLsham, Norwich.

1 The publication of this letter has been unintentionally delayed.-EDIt. Groc. MAG. 